\title{
The Brazilian investment in science and technology
}

R. Pinheiro-Machado and P.L. de Oliveira
Laboratório de Artrópodes Hematófagos, Departamento de Bioquímica Médica, Instituto de Ciências Biomédicas, Universidade Federal do Rio de Janeiro, Rio de Janeiro, RJ, Brasil

\section{Correspondence \\ R. Pinheiro-Machado \\ Laboratório de Artrópodes \\ Hematófagos \\ Departamento de Bioquímica Médica \\ ICB, CCS, UFRJ \\ 21941-590 Rio de Janeiro, RJ \\ Brasil \\ Fax: + 55-21-270-8647 \\ E-mail: rcpmachado@ bioqmed.ufrj.br}

Research supported by CNPq, FINEP, PRONEX, PADCT and Howard

Hughes Medical Institute.

Received June 5, 2001

Accepted September 17, 2001

\section{Abstract}

An analysis of Brazilian federal expenditures in science and technology is presented is this study. The 1990-1999 data were compiled from records provided by two federal agencies (MCT and CNPq) responsible for managing most of the national budget related to these activities. The results indicate that the federal investments in Brazilian science and technology stagnated during the last decade (US\$ 2.32 billion in 1990, US\$ 2.39 billion in 1996, and US\$ 2.36 billion in 1999). In contrast, a great increase in private investments in research was acknowledged both by industry and by the government during the same period, from US\$ 2.12 to US\$ 4.64 billion. However, this investment did not result in an increase in invention patents granted to residents (492 in 1990 and only 232 in 1997) or in a reduction of patent costs. Despite this unfavorable scenario, the number of graduate programs in the country has increased two-fold in the last decade and the contribution of Brazilians to the database of the Institute for Scientific Information has increased 4.7-fold from 1990 (2,725 scientific publications) to 2000 (12,686 scientific publications). Unstable federal resources for science, together with the poor returns of private resources in terms of developing new technologies, may jeopardize the future of Brazilian technological development.

\section{Key words}

- Science and technology

- Research and development

- Patents

- Technological innovation

- Scientific publication

.....................

\section{Introduction}

The construction and evolution of modern scientific and technological capacity in Brazil began in the fifties, following the ideas originally proposed by Vanevar Bush (1). In his view, science was "an endless frontier" and all fields of knowledge deserved government support. The main idea was that investment in basic science would definitely result in technological development. Therefore, technological innovation obviously depended on investments in research and development (R\&D) $(2,3)$. Dur- ing the period from 1968 to 1980 , Brazil experienced an economic expansion and, according to Schwartzman et al. (3), there was a rapid growth in scientific and technological investment because of the government's concern with the country's technological capability. The government applied money to a wide range of projects, constructing a scientific complex that covered almost all branches of knowledge. As evidence for the success of this policy we may mention: 1) the enhanced enrollment in universities, where the number of students rose 21.5-fold from 1961 to 1998 (4); 2) expansion in the number of graduate 
courses, which increased from 672 (1975) (5) to 1291 (1997) (6), and 3) an increase in the Brazilian contribution to publications in international scientific journals from 0.29 (1981) (7) to $1.11 \%$ (2000) (8) in relation to worldwide scientific publications.

In Brazil, as well as in other Latin American countries, investment in science increased during the late 1970's and early 1980's, keeping pace with economic growth in the region. However, investments in science and technology (S\&T) were curtailed when these countries began to have difficulties in paying their large debts to international banks. This situation began to change in 1990, when a new wave of investment in science occurred (9).

According to the Brazilian Ministry of Science and Technology (MCT), investment in S\&T is now growing, reaching a total of US\$ $9 \times 10^{9}$ in 1997 , corresponding to $1.13 \%$ of the gross domestic product (GDP) $(10,11)$. Most industrialized countries invest more than $2 \%$ of their GDP in R\&D. South Korea, a country that is approaching industrialization, in this same year invested $2.8 \%$ of its GDP in S\&T (12). Nevertheless, according to MCT data, Brazil's level of investment in 1997 lies in a range similar to that of some developed countries such as Italy (1.05\% of GDP) and Canada (1.64\% of GDP) (13).

The aim of the present study was to analyze the amount and effectiveness of Brazilian investments in S\&T during the 1990's, focusing on federal expenditures and comparing data published by the agencies that administer this money with line items from the national budget.

\section{Methods}

Data on Brazilian investments in S\&T were obtained from official publications by the MCT and by the National Council for Scientific and Technological Development (CNPq), as well as from the national budget, accessed via internet at the National Con- gress site (14). The data obtained were used to identify national expenditures on S\&T, focusing primarily on federal investments from 1990 to 1997, the period that is covered by published MCT and CNPq reports.

The national budget figures, available for 1995 to 1999 , were used to find expenditures allocated to federal institutions that devote more than $80 \%$ of their resources to S\&T. Some of these institutions are directly subordinate to MCT, such as CNPq, the National Foundation for Scientific and Technological Development (FNDCT) and the Agency for the Financing of Studies and Projects (FINEP). Other institutions are linked to different Ministries (Agriculture, Education, Air Force, Health, Energy, Navy, Industry and Trade, Army, and Environment): National Council for Graduate Studies (CAPES), Brazilian Agriculture Research Corporation (EMBRAPA), Oswaldo Cruz Institute (FIOCRUZ), National Council for Nuclear Energy (CNEN), National Institute for Educational Research (INEP), and Commission for Sea Resources Studies (SECIRM) (15).

We also used the national budget figures to obtain data on funding according to type of expenditure on S\&T: graduate studies and fellowships, basic and applied research, experimental development, metrology, hydrology studies, quality control, scientific and technological information, geological surveys, environmental surveys, trademarks and patents, and human resources training. This information was used to provide one or two years of more recent data that overlap the available MCT figures, and also allowed us to extend our comparison to 1999.

To relate Brazilian efforts in S\&T programs to current economic indicators we correlated investment with the GDP obtained via internet from the Brazilian Ministry of Treasury (16). All values are reported as 1997 US dollars and the conversion was performed according to the following methodology: for the national investment in S\&T 
from 1990 to 1996 our data were obtained from CNPq and MCT already expressed as 1996 R\$. They were first converted to 1997 $\mathrm{R} \$$ average consumer price index (IGP-DI = 1.0748) and then to 1997 US dollars according to the average dollar value (R\$ $1=$ US\$ 1.078) used by the Ministry of Treasury. The values corresponding to 1998 and 1999 were converted to $1997 \mathrm{R} \$$ using the IGP-DI of each year and then to 1997 US dollars. The GDP was also converted to 1997 US dollars using the same methodology (17).

Investment by the industrial sector was also obtained from MCT reports (11). The Ministry uses a database created by the National Association for Industrial Development (ANPEI), which is devoted to collecting data from Brazilian industrial companies that invest in R\&D. The ANPEI database represents more than 1,100 industries that are responsible for $42 \%$ of Brazil's industrial GDP (18).

The number of fellowships granted by CNPq from 1980 to 1999 was obtained via the CNPq site (19) and the number of fellowships granted by CAPES was obtained from the Diretoria de Programas/CoordenaçãoGeral de Programas no País/Coordenadoria de Desenvolvimento Setorial from the institute (20). The Brazilian contribution to the world scientific production from 1975 to 1999 was obtained from the Web of Science site, made available by the Institute of Scientific Information (8). The number of patents granted to industries that contribute data to the ANPEI database was taken from the ANPEI site (18). The patents granted to residents in the country in the category of inventions were obtained from the National Institute of Industrial Property (INPI) site (21). Patents involving only design were tabulated separately (see Results).

In order to regulate tax incentives granted to the productive sector the Brazilian government created a law in 1993 (Law No. 8661/93) (22) to stimulate technological development in industry and agriculture through investment in R\&D. The concept of technological capability adopted by this law covers a gamut of activities ranging from the development of research by industry to selection, absorption, improvement and dissemination of national or foreign technologies. This law was modified in 1997 by law No. 9532/97 (23) to stimulate the private sector to invest in $R \& D$ and to develop partnerships with research institutes and universities. The implementation of this law created a program to support industrial capability that is divided into two modalities, one for industry and the other for agriculture (24).

In 1995, the Brazilian Pluriannual Plan was approved taking into account an increase of private expenditure in S\&T, and in addition other laws were created to stimulate national technology. Regulations to implement these measures were elaborated and nowadays there are four laws to regulate incentives, law No. 8661/93 explained above, law No. 8248/91 directed at the production of software and hardware, and laws No. 8010/90 and No. 8032/90 that are designed to allow public and private research institutes, respectively, to import research equipment without paying custom taxes (25).

\section{Results and Discussion}

\section{Brazilian investment in science and technology}

Data published by the Brazilian MCT show an absolute growth of almost $70 \%$ in national investment in S\&T between 1990 and 1996, changing from US\$ 6.41 billion in 1990 that represents $1.17 \%$ of the GDP (US\$ 549.56 billion) to US $\$ 10.25$ billion in 1996 , which represents $1.3 \%$ of the GDP (US\$ 790.92 billion) (11).

Based on the guidelines set out in the Canberra Manual (26), a protocol used by the Brazilian MCT, total S\&T investment in Brazil is represented by the sum of government spending (federal and state, including 
salaries paid to university professors), tax incentives granted to industries, investment by private and non-private industry, loans granted by FINEP, and salaries paid to private university teachers. Figure 1 shows the amount spent on $S \& T$ according to different funding sources from 1990 to 1996 and the total national investment, which is the sum of expenditures in the period $(11,15,24,27)$.

Figure 1. Brazilian expenditures in science and technology. Categories are defined according to the Canberra Manual (26). The total investment per year is the sum of expenditures from the following funding sources: federal government, industry, tax incentives granted to industries, state funding agencies and salaries for private university teachers. Values were converted to 1997 US dollars as explained in the Methods section. Source: CNPq-1 (federal expenditures) MCT/FINEP (tax incentives) and MCT-2 (other investments).

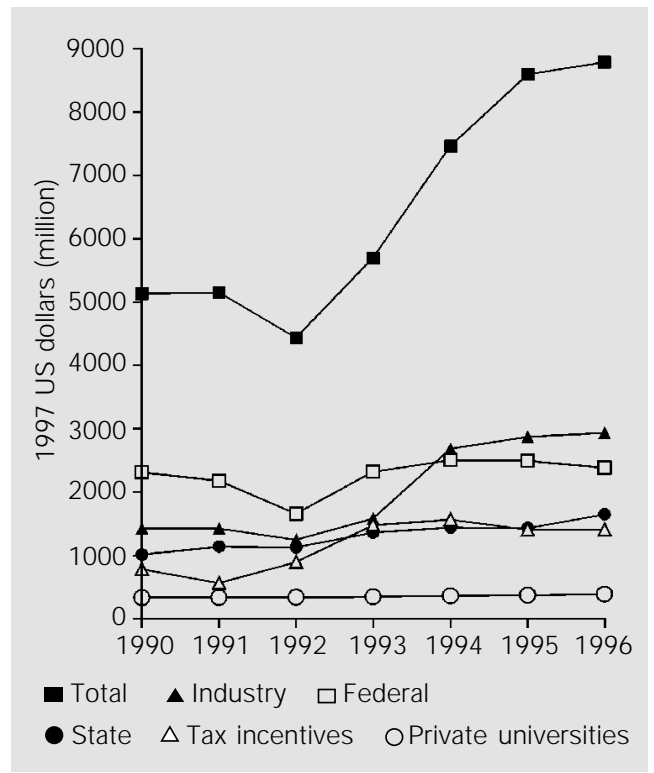

Figure 2. Funds allocated to the principal federal institutions that carry out or support scientific and technological activities. "Others" refers to INEP and SECIRM. FINEP funds in 1999 are partial. Values were converted to 1997 US dollars as explained in the Methods section. The list of abbreviations is also given in the Methods section. Source: National Budget and FINEP (Ref 28).

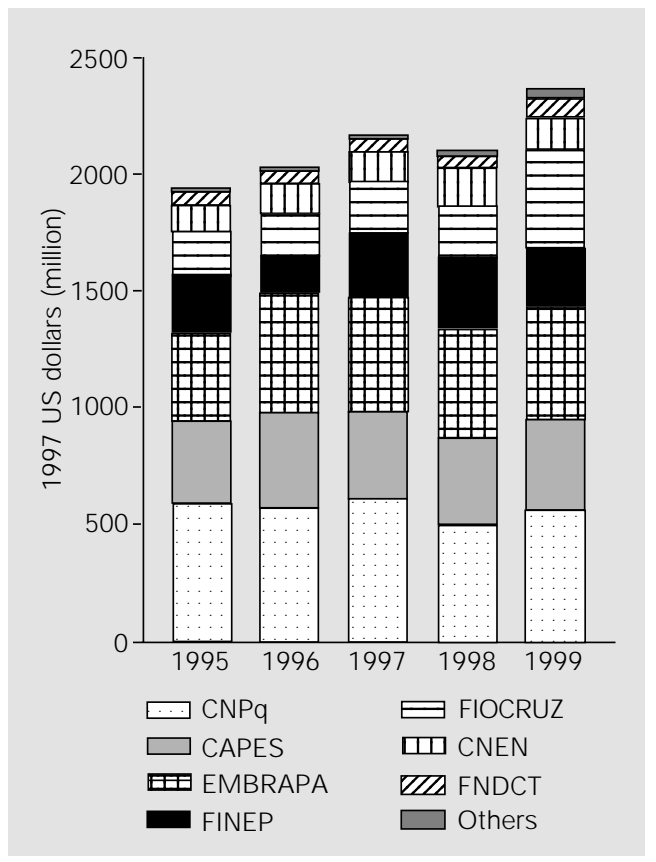

\section{Government expenditures}

Federal spending on S\&T, according to MCT, includes tax incentives granted to industries. However, in this section we will treat federal spending without considering tax incentives, which will be discussed in another section.

In 1990, according to $\mathrm{CNPq}$ (using the national budget as data source), federal funds were US\$2.32 billion and represented $45 \%$ of the S\&T budget (US\$ 5.14 billion). In 1996 federal funds increased to US\$ 2.39 billion. Despite the increase in absolute value, federal spending in 1996 represented a smaller fraction of the total S\&T budget $(27.2 \%)$, suggesting that federal funds decreased (15).

However, federal investment data reported by both $\mathrm{CNPq}$ and MCT have not been updated since 1996 and 1997, respectively. We obtained Brazilian budget data directly from the national congress site (available from 1995 to 1999) in order to update these figures. Federal investment in S\&T is extremely concentrated on a few main research or funding institutions that either support or carry out scientific and technological activities. These are CNPq, FNDCT, FINEP, CAPES, EMBRAPA, FIOCRUZ, CNEN, INEP and SECIRM. In 1996, for example, these institutes together received $74.5 \%$ of all federal S\&T funds. The other $25.5 \%$ were distributed as follows: $9.1 \%$ for military research, $3 \%$ to federal universities, $2.5 \%$ for MCT administration, and $10.9 \%$ to other institutions (15). From 1995 to 1999 (the period available through the internet) (14), the budget of these institutions decreased mainly for FINEP (51\% less), CNPq (30\% less) and CAPES (15\% less), as shown in Figure 2.

An analysis of the Brazilian national S\&T budget according to category of expenditure is shown in Figure 3. These data reinforce the conclusion that federal funds are decreasing, mainly in modalities of expendi- 
ture that are linked to $\mathrm{R} \& \mathrm{D}$ such as basic research and human resources training. In 2000 , for example, CNPq offered a funding program of only $\mathrm{R} \$ 30 \times 10^{6}$ (US\$ 15 million) to basic research projects directly requested from the agency by the whole Brazilian scientific community, which represents 11,760 active research groups with a total of 49,956 researchers (29).

The decline in funding can also be inferred from the number of fellowships granted by CNPq and CAPES for M.Sc. and Ph.D. students (Figure 4). From 1990 to 1995, there was a $47 \%$ increase in the number of fellowships granted by these agencies. However, from 1995 to 1999 the number of graduate fellowships declined from 27,955 to $25,883(19,20)$. This reflects a decrease in M.Sc. fellowships: in 1990, 15,716 fellowships were awarded; this increased by $27 \%$ to a total of 19,960 in 1995, but in 1999 there were only 16,384 , almost the same number as at the beginning of the decade. The impact on M.Sc. fellowships was greater at $\mathrm{CNPq}$ where a 52\% decrease was observed from 1995 to 1999 . This is consistent with the decrease in funds allocated to $\mathrm{CNPq}$ that appeared in the national budget for 1999 than in funds allocated to CAPES (Figure 2).

Figure 5 shows a comparison between federal investment according to CNPq (Figure 1) and our budget update for institutions (Figure 2) and modalities of expenditure on S\&T (Figure 3). Overall, the total investment in 1995/1996 (where data from all three sources overlap) was similar regardless of the source of information and almost the same as the value reported by CNPq. The inset in Figure 5 shows the percentage of

Figure 5. Federal funding for science and technology according to CNPq (squares), Figure 2 (filled circles), and Figure 3 (open circles). The inset shows the percentage of federal investment in institutions (filled circles) and in the main modalities of science and technology (open circles) in relation to the total national budget from 1995 to 1999. Source: National Budget, CNPq and FINEP.

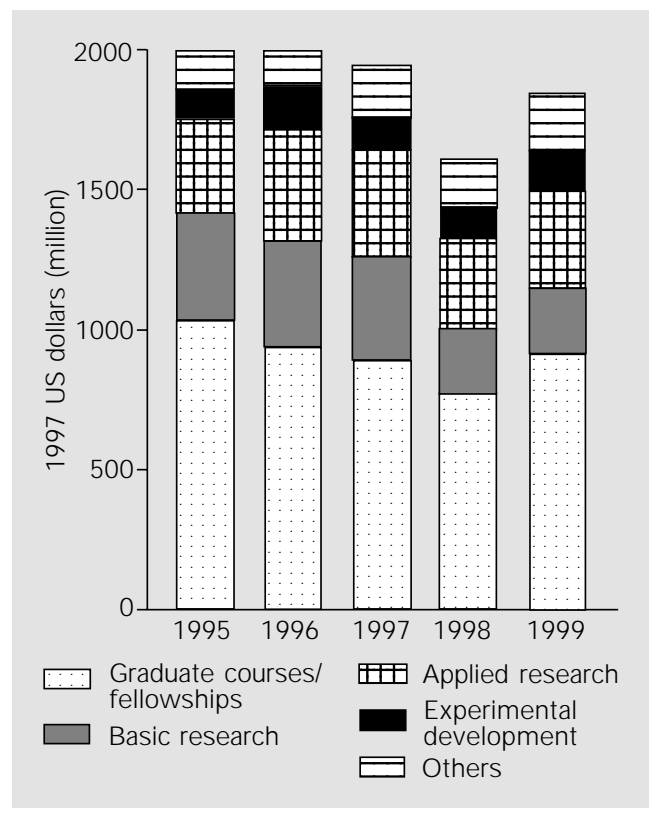

Figure 3. Federal funds disbursed for science and technology according to type of activity. "Others" refers to metrology, hydrology, quality control, scientific and technological information, geological surveys, trademarks and patents, and environmental surveys. Values were converted to 1997 US dollars as explained in the Methods section. Source: National Budget.

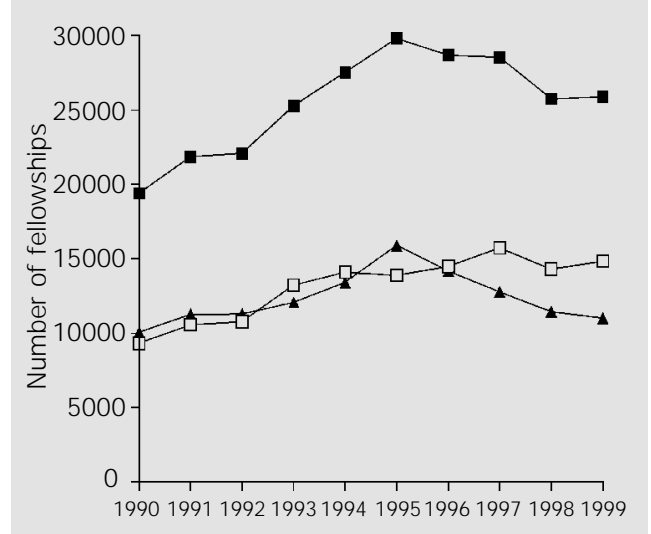

Figure 4. Fellowships awarded by federal agencies for graduate study in the country and abroad by CNPq (triangles), CAPES (open squares), and total (filled squares). Source: CNPq and CAPES.

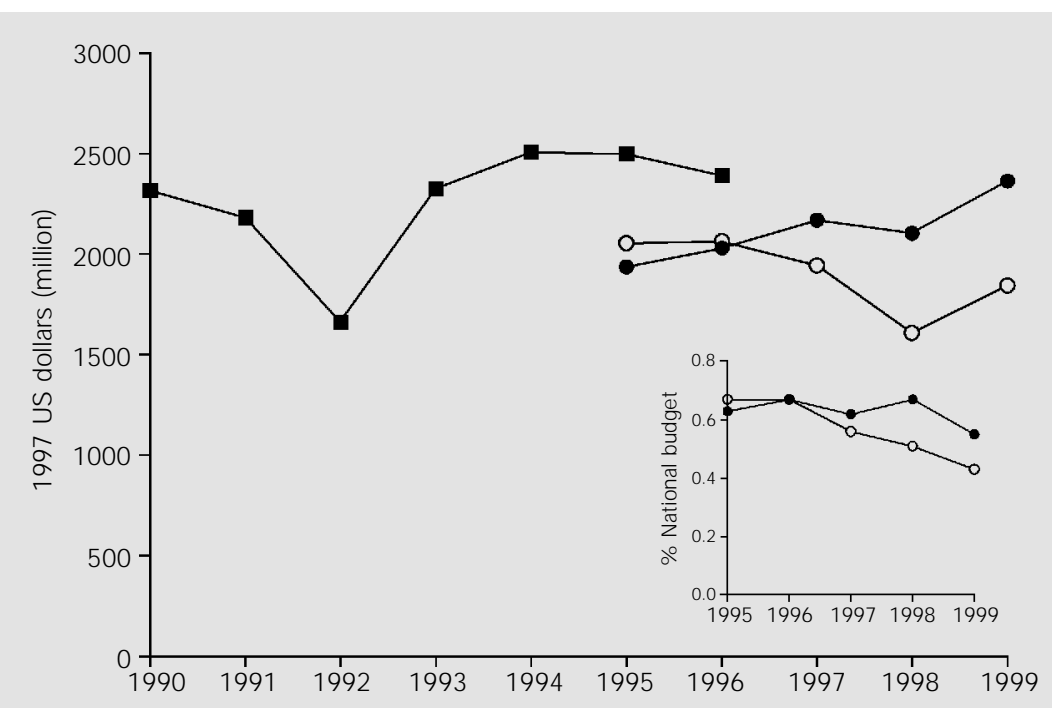


Figure 6. Brazil's share of world scientific publications from 1990 to 1999. Source: Web of Science. federal investment in relation to the total national budget from 1995 to 1999 (period available). According to the national budget, the decrease in the budget of the main institutions during the period was from 0.63 to $0.55 \%$ in relation to the total federal budget. The main modalities of expenditures on S\&T decreased from 0.67 to 0.43 during the same period. These data support the idea that the institutes and the main R\&D modalities are losing ground.

According to May (30), in a selected group of countries that together account for $80 \%$ of the world's total investment in R\&D, the government is in most cases the main source of funds for basic science, which is mainly carried out at universities. In Brazil, basic science is also a university enterprise. According to de Meis and Leta (31), the research centers that produce most of the scientific papers are universities. In 1995, for example, $75.2 \%$ of all active researchers were working at universities (15).

Despite the fact that funds for basic science are decreasing (Figure 3), Brazil's share of world scientific articles increased from 1981 to 2000. Figure 6 shows that the Brazilian contribution during the nineties increased 2.4-fold from $0.46 \%$ of world publications in 1990 to $1.11 \%$ in 2000 . The impact on this trend of the decrease in the number of graduate fellowships and in federal investment that began in 1995 is likely to be felt in the

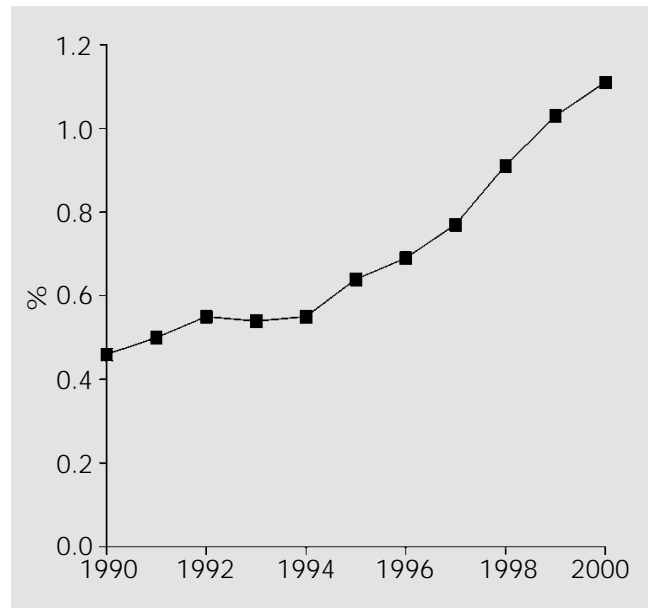

next few years.

Figure 1 also shows that state research funds (20 states in 1996) have increased by 1.6-fold during the period. In São Paulo and Rio de Janeiro, the number of scientific publications increased by a factor of 3.26 and 2.86, respectively, from 1990 to 2000; in other states (Minas Gerais, Rio Grande do Sul, Santa Catarina and Paraná) the scientific contribution increased, on average, by a factor of 4.5 (8). These data suggest that funding by some state research agencies is beginning to contribute significantly to scientific development in the country.

\section{University professors}

A UNESCO recommendation released in 1978 identified three different categories of expenditures on S\&T: research and development, technological services, and education and training in S\&T (32). Part of the salaries paid to university professors is included in the last category. Since part of the salaries paid to federal and state professors is computed in federal expenditures, Figure 1 separately shows the amount paid annually to private university teachers, about US\$ 350 million from 1990 to 1996 . However, this guideline, which is also a norm of the Canberra Manual (26), may not apply to the Brazilian situation. Despite the fact that private universities account for $65 \%$ of student enrollment (4), they were responsible for only $1.02 \%(\mathrm{~N}=887)$ of Brazil's scientific publications from 1990 to $2000(\mathrm{~N}=86,939)$. Among the 82 private universities, only 37 contributed to the Brazilian scientific effort by publishing in indexed journals (8).

\section{Industrial research and development}

Figure 1 shows the amount spent by industry on R\&D, as estimated by MCT: the values reported in the ANPEI database were multiplied by 1.33 (in order to include companies not listed by ANPEI) and added to the 
investments reported by industries that were granted tax incentives under the laws set up to stimulate R\&D activities (1). We note that this procedure tends to inflate the investment calculation, since adhesion to ANPEI is voluntary, and therefore the figures are likely to include most of the companies that actually do invest in R\&D. The companies that do not belong to ANPEI are also not likely to carry out R\&D activities.

Using the ANPEI database, the MCT has estimated that industrial spending on R\&D more than doubled between 1993 and 1996 (Figure 1). This growth would be expected to bring an increase in productivity. Patents are considered to be an indicator of industrial performance. Kondo $(33,34)$ has shown that in Japan there is a positive correlation between the rise in $\mathrm{R} \& \mathrm{D}$ expenditures and the increase in the number of patent applications. Thus, the increase in R\&D investment by Brazilian industries should be accompanied by an increase in the number of patent applications. According to ANPEI, the number of patents granted to industries that comprise their database is less than one per year per company (18), suggesting that investments by these firms are not producing technological innovations. This problem may be related to the profile of the firms that integrate the database. According to Scherer (35), patenting activity varies among different industrial sectors and according to other characteristics such as the size of the company.

We checked the number of patents granted to residents by INPI (21) from 1990 to October 2000 (Figure 7). There was an increase in the number of patents granted during the period, but these data included patents granted to individuals as well as to companies. It is important to note that this increase in domestic patents mainly reflects an increase in the number of design patents (defined as describing new and non-ornamental design features in an already existing article of manufacture) as shown in Figure 7. These patents protect only the appearance of the article, not its structural or functional features. In 1999, for example, of 3,595 patents granted to residents, $80 \%$ were design patents and only $12 \%$ were patents of invention, defined as innovative processes or devices. The number of invention patents (lower curve in Figure 7) does not show a significant increase over the last decade. These data suggest therefore that industry expenditures may not reflect real technological advances.

\section{Tax incentives}

Tax incentives are widely employed in different countries as a means of stimulating private investments in S\&T. The international experience reveals that tax incentives are the principal instrument used to induce industrial $R \& D$ activities and to integrate the knowledge produced at universities and research institutes with industrial technological needs. According to Marcovitch et al. (36), the main incentives granted in different countries are deductions from taxable income of expenditures in R\&D, rapid depreciation of machines and equipment, and reductions in import taxes. Countries that apply these incentives include, for example, the United States, Japan, France, Canada, Germany, Australia, South Korea, Taiwan, United Kingdom, Austria, Holland, and Belgium. The treatment of R\&D tax systems varies extensively between countries and over time depending on differential inflation and economic interests. Canada, for example,

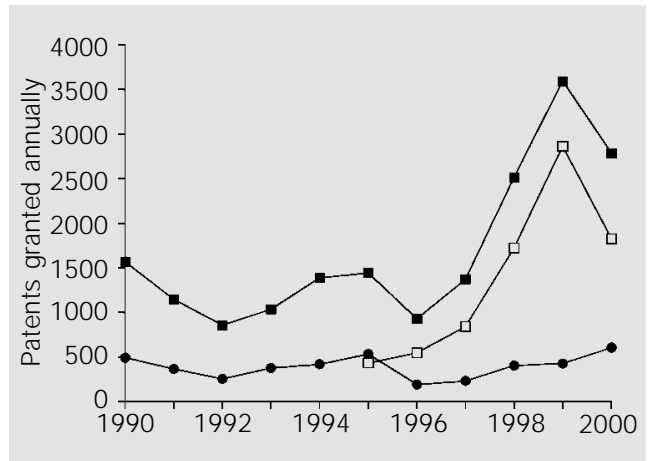

Figure 7. Patents granted as an indicator of successful investment in research and development. The figure shows the total number of patents granted to Brazilian companies and individuals (filled squares), and subdivided according to class, i.e. invention (circles) or design (open squares). Data for 2000 are partial (J anuary-October). Source: INPI. 
has been providing income tax incentives since 1944 including accelerated deductions, incremental bonus deductions and investment tax credits ( $20 \%$ or more). In general, current expenditures that are eligible for tax incentives include salaries of employees directly engaged in $R \& D$, the cost of materials consumed, costs related to machinery and equipment used (90\% or more), and expenditures incurred by contractors.

In Brazil, the main incentives are a 90\% tax reduction for equipment importation, deduction of costs with employees and royalties paid to third parties, accelerated depreciation of equipment and machines, and tax reductions.

The amount granted in tax incentives from 1990 to 1996 in Brazil is shown in Figure 8. Between 1991 and 1993 there was a sharp increase to a relatively constant value around US\$ 1.4 billion.

As a whole, our analysis indicates that the 1990's were a decade of stagnation for investments in S\&T. The stagnant funding of public science (Figures 2 and 3), allied to poor returns from investment in technology (Figure 7), certainly jeopardizes the future of Brazilian technological development.

Despite the decrease in funds for basic research (Figure 3), the scientific community production, consisting mainly of basic and applied research, is becoming more efficient. In 1995, for example, the cost of a scientific publication (federal expenditures

Figure 8. Tax incentives granted to stimulate industrial investment in research and development. Data for 1995 were not available. Source: MCT/FINEP.

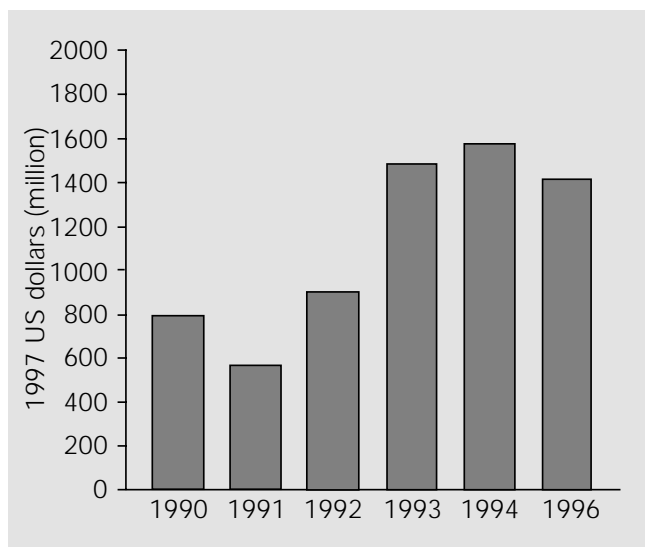

on basic and applied research/number of publications) was US\$ 106.82 thousand per paper, and in 1999, the cost was 55\% less (US\$ 48.36 thousand per paper). On the other hand, there was a two-fold increase in company declared expenditures and tax incentives to industry (in 1990 US\$ 2.12 billion was spent, and in 1997, expenses were US\$ 4.64 billion) (Figure 1). This increase in funds did not bring an increased production of invention patents granted to residents (492 in 1990 and only 232 in 1997); in fact, the number of patents decreased two-fold and the cost of a patent increased at the same proportion.

The data suggest that the new investments in S\&T (industry expenditures and tax incentives) are not reflecting technological development. The "productive" investment in S\&T (federal and state funds), in 1997, for example, represented half of the total expenditures (US\$ 4 billion), which represented $0.5 \%$ of the GDP.

According to McMillan et al. (37), public science plays an important role in industrial development, mainly in biotechnology and pharmaceutical industries, because this kind of enterprise depends on the knowledge produced at universities and research institutes to develop technological innovations.

Therefore, to enhance technological development it is important to maintain federal funds for scientific activities in order to obtain the knowledge that could sustain national production of new processes and devices. Moreover, it is important that the Brazilian industries apply funds to "real" research and not merely limit their effort to quality control and minor modifications of products to conform to costumer requirements, an approach that cannot be considered as industrial research and that will not sustain technological development. According to Albuquerque (38) and the United States Patent and Trademark Office (USPTO) (39), among all Brazilian industries, there are three that had the largest number of patents granted 
by USPTO during the 1980-2001 period, i.e., Petrobrás (134 patents), Embraco (53 patents), and Metal Leve (32 patents). Except for Petrobrás which had six patents granted per year, the others have two patents or less per year. Rarely is real innovation pursued, even by commercially successful companies such as Embraer, which has no patent granted by USPTO or by INPI.

\section{Acknowledgments}

We are grateful to Leopoldo de Meis and Martha Sorenson, UFRJ, for a critical reading of the manuscript.

\section{References}

1. Bush V (1990). Science: The Endless Frontier. National Science Foundation, USA, J uly 1945, reprinted 1960, 1980 and 1990, Washington, DC, USA.

2. Beiguelman B (1997). Reflexões sobre a pós-graduação. In: Anais do Simpósio A Pós-Graduação no Brasil, UFRJ, Rio de J aneiro, RJ , Brazil, 33-48.

3. Schwartzman S, Krieger E, Guimarães EA \& Bertero CO (1993). Ciência e Tecnologia no Brasil: Uma Nova Política Para um Mundo Global. Documento síntese do estudo sobre "O Estado Atual e o Papel Futuro da Ciência e da Tecnologia no Brasil". Escola de Administração de Empresas, Fundação Getúlio Vargas, São Paulo, SP, Brazil.

4. INEP - Instituto Nacional de Estudos e Pesquisas Educacionais. Available at: http://www.inep.gov.br. Accessed April 2001.

5. Resende SM (1998). Pós-graduação e pesquisa no Nordeste. In: Anais do Simpósio A Pós-Graduação no Brasil. UFRJ, Rio de J aneiro, RJ , Brazil, 109-132.

6. CAPES - Coordenação de Aperfeiçoamento de Pessoal de Nível Superior. Available at: http://www.capes.gov.br. Accessed December 2000.

7. Leta J, Lannes D \& de Meis L (1998). Human resources and scientific productivity in Brazil. Scientometrics, 41: 313324.

8. Institute for Scientific Information (ISI) via Web of Science. Available at: http:// webofscience.fapesp.br. Accessed December 2000.

9. Ayala FJ (1995). Science in Latin America. Science, 267: 826-827.

10. MCT-1 - Ministério da Ciência e Tecnologia (1998). Ciência \& Tecnologia nos Anos 90: A Década do Crescimento. MCT, Brasília, DF, Brazil.

11. MCT-2 - Ministério da Ciência e Tecnolo- gia (1997). Indicadores Nacionais de Ciência e Tecnologia 1990-96. MCT, Brasília, DF, Brazil.

12. UNESCO - United Nations Educational, Scientific and Cultural Organization. Available at: http://unescostat.unesco.org/en/ stats/stts0.htm. Accessed J une 2000.

13. OECD - Organization for Economic Cooperation and Development, Science and Technology Indicators. Available at: http:// www.dti.gov.UK/ost/setstats/data/7/ tab7_1.htm. Accessed September 2000.

14. National Congress. National Budget. Available at: http://www.camara.gov.br. Accessed J une 2000.

15. CNPq-1 - Conselho Nacional de Desenvolvimento Científico e Tecnológico. Despesas Realizadas pela União em Ciência e Tecnologia: 1987-96. CNPq, Brasília. Available at: http://www.cnpq.br/publicações/ druct96. Accessed September 1999.

16. Ministério da Fazenda. Informações Adicionais - PIB, Moedas, Índices de Preços e Fonte de Dados. MF, Brazil. Available at: wysiwyg://106/http://www. receita.fazenda.gov.br/Arrecadação/ Carga_Fiscal/1999/infoadic.htm. Accessed December 2000.

17. American Average Consumer Price Index. Available at: http://stats.bls.gov/cpihome. htm. Accessed December 2000.

18. ANPEI - Associação Nacional de Pesquisa e Desenvolvimento das Empresas Industriais. Indicadores Empresariais de Inovação Tecnológica: Síntese dos Dados no Período 1993-1997. Available at: http:// eu.ansp.br/ anpei/link3.htm\#base. Accessed J une 1998.

19. CNPq-2 - Conselho Nacional de Desenvolvimento Científico e Tecnológico. Séries Históricas do Fomento do CNPq - 1995/ 98. Available at: http://www.cnpq.br/sup/ fomento/tabela9.html. Accessed April 2000 .
20. CAPES/DPR/SPP/CDS - Fundação Coordenação de Aperfeiçoamento de Pessoal de Nível Superior - Diretoria de Programas - Coordenação Geral de Programas no País - Coordenadoria de Desenvolvimento Setorial. Relatório de concessão de bolsas por área. File obtained via e-mail: henni.santos@capes.gov.br.

21. INPI - Instituto Nacional de Propriedade Industrial. Available at: http://www.inpi. gov.br. Accessed August 2000.

22. MCT - 3 - Ministério da Ciência e Tecnologia (1998). Legislação Básica de Ciência e Tecnologia. MCT, Brasília, DF, Brazil, 202.

23. MCT-3 - Ministério da Ciência e Tecnologia (1998). Legislação Básica de Ciência e Tecnologia. MCT, Brasília, DF, Brazil, 72.

24. MCT/FINEP - Ministério da Ciência e Tecnologia - Financiadora de Estudos e Projetos (1998). Estudos dos Impactos e Resultados dos Incentivos Fiscais de que Tratam as Leis 8.248/91 e 8.661/93. Brasília, DF, Brazil, 136.

25. MCT-4 - Ministério da Ciência e Tecnologia. Plano Plurianual de Ciência e Tecnologia do Governo Federal - PPA 1996/99. Brasília, DF, Brazil, 141.

26. OECD - Organization for Economic Cooperation and Development (1995). The Measurement of Scientific and Technological Activities: Manual on the Measurement of Human Resources Devoted to Science and Technology "Canberra Manual", Paris, France.

27. Ministério da Fazenda - Secretaria da Receita Federal. Consolidação dos Benefícios Tributários por Receita e Modalidade de Benefício. Available at: http://www. receita.fazenda.gov.br. Accessed August 2000.

28. FINEP - Financiadora de Estudos e Projetos. Desempenho Financeiro. File obtained via e-mail: mferraz@finep.gov.br.

29. CNPq-3 - Conselho Nacional de Desenvol- 
vimento Científico e Tecnológico. Research Groups. Available at: http://www. cnpq.br/plataformalattes/dgp/versao4. Accessed May 2001.

30. May RM (1998). The scientific investments of nations. Science, 281: 49-51.

31. de Meis L \& Leta J (1996). O Perfil da Ciência Brasileira. Editora UFRJ, Rio de J aneiro, RJ , Brazil.

32. UNESCO - United Nations Educational, Scientific and Cultural Organization (1978). Recommendation Concerning the International Standardization of Statistics on Science and Technology. Paris, France.
33. Kondo M (1995). Dynamic analyses on the relation between R\&D and patent applications in J apan. J ournal of Science Policy and Research Management, 10: 193-204.

34. Kondo M (1999). R\&D dynamics of creating patents in the J apanese industry. Research Policy, 28: 587-600.

35. Scherer FM (1983). The propensity to patent. International J ournal of Industrial Organization, 1: 107-128.

36. Marcovitch J, Sbragia R, Stal E \& Terra J CC (1991). Inovação tecnológica e incentivos fiscais. Revista de Administração,
26: $75-83$

37. McMillan GS, Narin F \& Deeds DL (2000). An analysis of the role of public science in innovation: the case of biotechnology. Research Policy, 29: 1-8.

38. Albuquerque EM (2000). Domestic patents and developing countries: arguments for their study and data from Brazil (19801995). Research Policy, 29: 1047-1060.

39. USPTO - United States Patent and Trademark Office. Available at: http://www. uspto.gov. Accessed December 2000. 